\title{
THE EFFECT OF MACROECONOMIC VARIABLES ON FISCAL SUSTAINABILITY IN INDONESIA, PERIOD 2004 Q1-2018 Q4
}

\author{
M. Latif Abdullah', Sunaryati² \\ 1,2Departmen of Sharia Economics, Sunan Kalijaga Yogyakarta State Islamic \\ University, Yogyakarta \\ 'Email: latifabdullah062@gmail.com (correspondence author) \\ 2Email: s_nartie@yahoo.com
}

\begin{abstract}
Fiscal sustainability illustrates the condition of a healthy government budget which can finance government spending without increasing debt supply. The purpose of this study is to analyze the impact of macroeconomic variables on fiscal sustainability which in this study fiscal sustainability is proxied as a government budget deficit. The data used in this study is the 2004Q1-2018Q4 time series data using the Vector Error Correction Model(VECM). The results showed that fiscal conditions in Indonesia are sustainable and macroeconomic variables such as domestic debt andinflation has a positive effect on increasing the government budget deficit. Whereas the variable state revenues and foreign debt negatively affect the government budget deficit.
\end{abstract}

Keywords : Fiscal Sustainability, Government Budget Deficit, Domestic Debt, Foreign Debt. 


\section{Introduction}

The economic crisis experienced by Indonesia in 1998 and 2008 had an impact on increasing government debt to cover the budget deficit. The government closes the budget deficit using debt financing, both domestic debt and foreign debt (Marisa, 2015). If the budget deficit using debt is not managed properly, according to Kuncoro (2011)the budget deficit will be a major problem for fiscal sustainability in Indonesia. Fiscal sustainability is a fiscal capability in implementing various government policies and programs by taking into account macroeconomic conditions, and maintaining the ratio of the country's debt to Gross Domestic Product (GDP) is fixed (Manurung, 2009).

Long term oriented debt management is needed to be able to achieve conditions of fiscal sustainability. The law has secured a maximum budget deficit (fiscal) ratio of 3 percent and a maximum debt ratio of 60 percent of GDP (Law No. 17 of 2003). Figure 1 presents data on the ratio of government debt to GDP from 2004-2018.

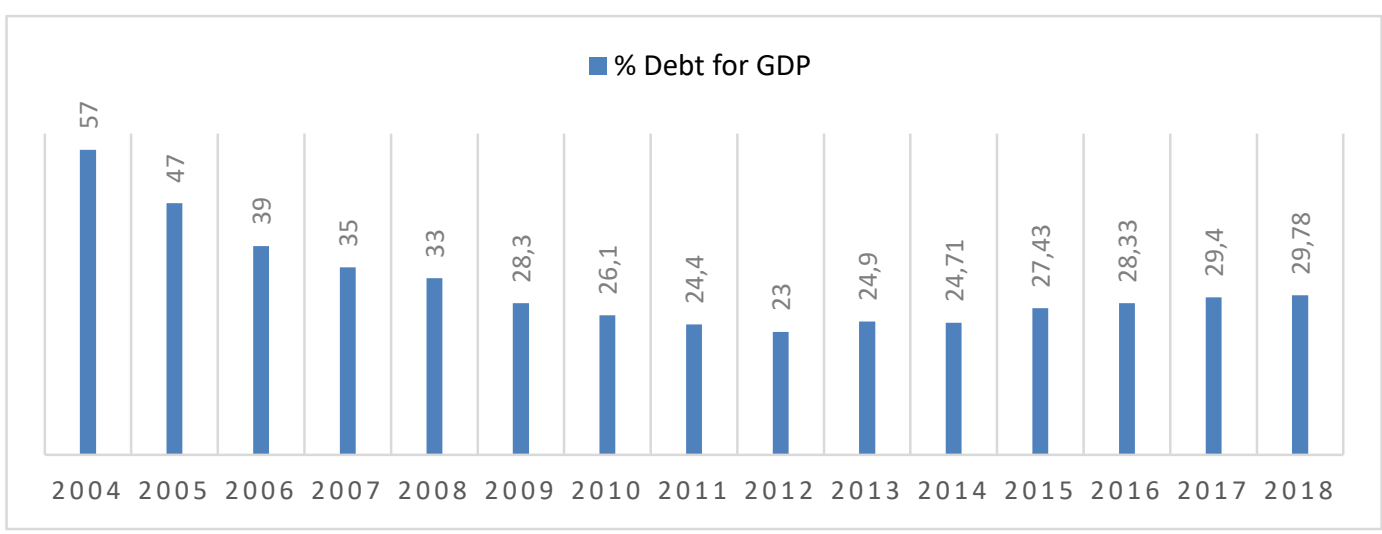

Figure 1. Government Debt Ratio to Indonesian GDP in 2004-2018 Source: Ministry of Finance (processed)

Based on Figure 1 it can be seen that the debt to GDP ratio in 2004 has approached the maximum limit of 57 percent of GDP, this number is reduced in the following years and the lowest reached 23 percent in 2012, during which the administration of President Susilo Bambang Yudhoyono focused the economy to reduce the government debt figure, until it shifted during the administration of President Joko Widodo the amount of government debt increased significantly each year, in 2017 the ratio of government debt to GDP was 27.43 percent until the end of 2018 of 29.79 percent. The increase in the ratio of government debt to GDP is a result of the budget deficit for infrastructure development financing.

In maintaining the mandate of Law No. 17 of 2003 the government seeks to maintain fiscal sustainability by keeping the budget deficit value below the 3 percent limit of national GDP. The government's efforts can be proven based on the observation graph in Figure 2 which shows that the magnitude of Indonesia's gross domestic product is 995.3 billion with a budget deficit in 2010 of 1,042 billion or $-0.7 \%$ of GDP and always shows an increasing trend until 2017 to be the highest point with a deficit budget of 2,098 billion or $-2.67 \%$ followed by a decrease in GDP of 86.5 billion compared to the previous year, then in 2018 the absorption of GDP increased again to 1,894 billion so that the magnitude of the budget deficit ratio decreased to $-2.19 \%$ of GDP or 2,220 billion. If the magnitude of the deficit is not maintained then Indonesia's fiscal sustainability will be threatened. 


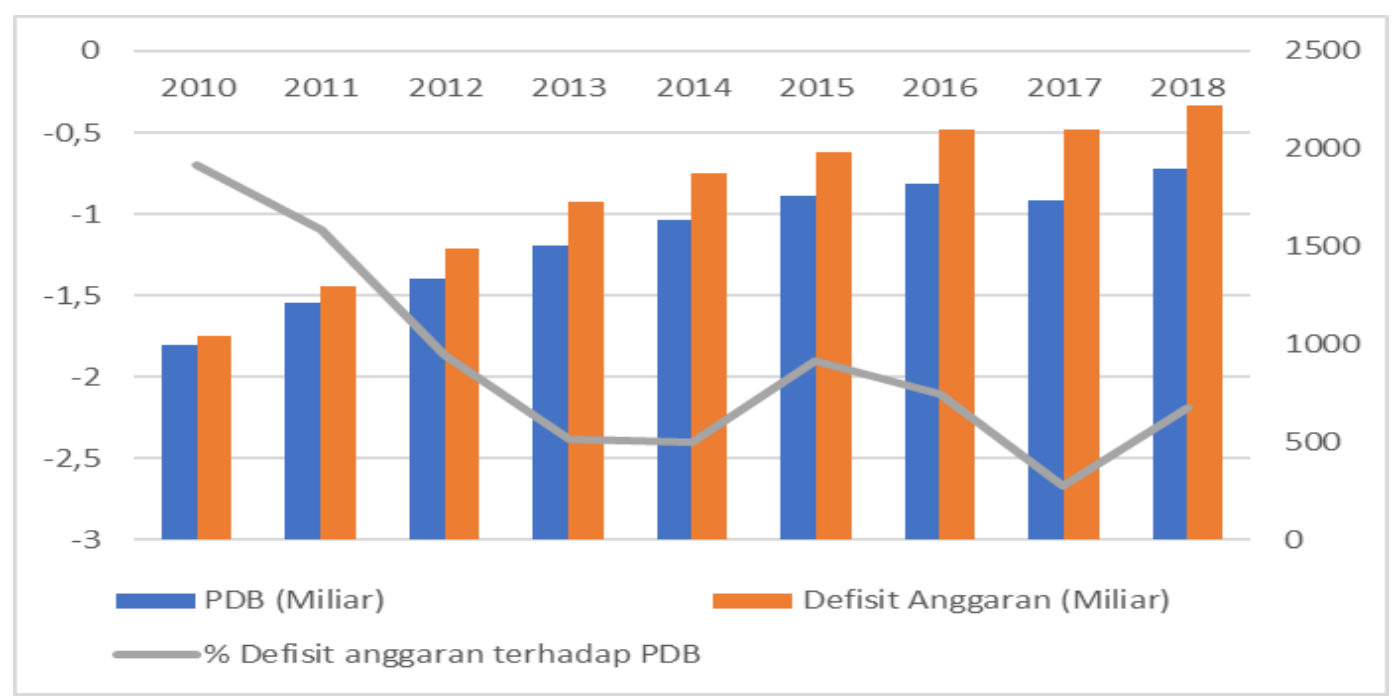

Figure 2. Graphic Government Budget Deficit Movement Source: Indonesia State Budget Realization $2018(\mathrm{BI}, 2018)$

Wardhono et al (2015)who examined the formation of a fiscal structure on the impact of foreign debt as a proxy for Indonesia's fiscal sustainability. VD (Variance Decomposition) test results show that Indonesian interest rates, inflation, and crude oil prices are more dominant in influencing fiscal sustainability. Another study conducted by Marisa (2015) related to Indonesia's fiscal sustainability. The result is variable government debt ratios, 3-month SPN interest rates, economic growth rates and exchange rates can affect the primary balance ratio. In addition, Indonesia's fiscal year 2000-2012 is in a sustainable condition.

Another empirical study conducted by Kuncoro(2011) examined the robustness of the Indonesian state budget in paying debts. The result is variables such as foreign debt, foreign interest rates, and primary surpluses push down the total government debt. In addition, this study states that in 1999-2009 the Indonesian budget was in the same position solvable.

In this paper, the authors attempt to examine fiscal sustainability in Indonesia by using a proxy for the budget deficit in 2004-2018 and analyze the impact of macroeconomic variables on fiscal sustainability in Indonesia.

\section{Literature Review}

Fiscal sustainability according to Burnside \& Dollar (2000)is defined as the ability of the government to maintain current expenditure, taxes and other policies in the long run without threatening the solvency of the government or the occurrence of default (failure to pay) on some promised obligations or expenditures.

Fiscal sustainability is related to a status in which the government budget can be financed smoothly without creating or encouraging an extraordinary increase in public debt (or money supply) throughout the year. If this status is fulfilled it means the government budget is said to be sustainable, or vice versa (Raymundo, 2016). According to Adams et al(2010) there are two concepts related to fiscal sustainability, including:

a. Static fiscal sustainability that reflects the government's ability to fund its spending budget from period to period.

b. Dynamic fiscal sustainability related to the ability of the government to pay off debt / obligations in the long run.

The definition of fiscal sustainability can also be understood using the model of government fiscal financing constraint (Cuddington, 1999). The model is stated by an equation that: 
Where:

$$
B_{+}=\left(1+r_{+}\right) B_{t-n}-S U R P B
$$

$\mathrm{B}_{+}=$Amount of outstanding debt in year $\dagger$

$r_{+}=$interest rate

SURPB $=$ surplus in primary balance.

The equation above explains that the amount of outstanding government debt is equal to the difference between interest and installments of government debt with a primary surplus. While the primary surplus itself is the difference between government revenues and expenditures excluding interest and debt installments. Based on equation (1) above can be reduced to:
$B+-B+n=r+B+n-S U R P B$
(2), or
$B=r+B t-n-S U R P B$

in which $B$ is the increase of government debt

The equation above can be concluded that when (1) $S U R P B=0$, the debt will increase as much as the interest on the previous debt. (2) If SURPB is lower than $r+B+n$, it means that the government's principal debt continues to increase, and if (3) SURPB is higher than $r+B t-n$, then the government's principal debt decreases. A budget deficit or surplus can be said to be sustainable if the primary balance produces a constant debt ratio.

Adams et al(2010) explained that fiscal sustainability in a country can be measured using various proxies such as the ratio of public debt to GDP, primary balance, ratio of budget deficit to GDP, and fiscal expenditure. Various studies related to fiscal sustainability have been carried out such as Kuncoro(2011) with the title "State Budget Resilience in Debt Payments" concluding that Indonesia's fiscal sustainability has not been achieved because it has a solvency in paying domestic and foreign debt. The source of this unsustainability is the burden of domestic debt which has increased far more rapidly than the increase in foreign debt.

In contrast to Hidayah's research (2015) which examines fiscal sustainability in Indonesia by using a proxy for primary balance, it concludes that Indonesia's fiscal conditions are sustainable. The results of the research state that debt has a nonlinear relationship to the primary balance where every increase in debt will reduce the primary balance with a declining acceleration, but with an increase in government debt the fiscal sustainability in Indonesia is still stable. In another study, Stoian \& Campeanu(2010) who examined the " Fiscal Policy Reaction in the Short Term for Assessing Fiscal Sustainability in the Long Run in the Central and Eastern European Countries" using a fiscal reaction function analysis tool explains that in the long run fiscal sustainability can be realized when public debt does not burden the government budget, then the government does not reduce spending, as well as tax targets and increase the money supply in the long run.

\section{Research Methods}

In this study, testing related to the influence of macroeconomic variables on fiscal sustainability was conducted during the period 2004-2018 with quarterly time format. Sources of research data are sourced from the ministries of finance, CEIC, IMF, BI and US Energy Information and Administration. Variables and sources of data acquisition are presented in Table 1.

Table 1. Operational Research Variables

\begin{tabular}{lcl}
\hline \multicolumn{1}{c}{ Variable Type } & Proxy Used & \multicolumn{1}{c}{ Data source } \\
\hline $\begin{array}{l}\text { Fiscal Sustainability } \\
\text { State Revenue }\end{array}$ & $\begin{array}{l}\text { Budget Deficit } \\
\text { State Revenue }\end{array}$ & $\begin{array}{l}\text { Ministry of Finance } \\
\text { State Financial Note along with } \\
\text { the State Budget }\end{array}$ \\
Government Debt & Debt d nature & $\begin{array}{l}\text { Directorate General of Debt } \\
\text { Dit }\end{array}$
\end{tabular}




\begin{tabular}{lll} 
& $\begin{array}{l}\text { of } \\
\text { domestic and } \\
\text { foreign debt } \\
\text { Inflation }\end{array}$ & $\begin{array}{l}\text { Management, World } \\
\text { Development Indikators, CEIC }\end{array}$ \\
$\begin{array}{ll}\text { Inflation } & \text { The IMF } \\
\text { Exchange rate } & \begin{array}{l}\text { Exhange rate } \\
\text { World Crude Oil Prices }\end{array} \\
\text { World crude oil } & \text { US Energy Information and } \\
\text { prices per Administration } \\
\text { barrel }\end{array}$ & \\
\hline
\end{tabular}

Fiscal sustainability in this study uses a proxy for the government's budget deficit to see the government's ability to maintain long-term solvency and use macroeconomic variables, such as state revenue, domestic debt, foreign debt, inflation, exchange rates and world crude oil prices as exogenous variables that are considered capable describe the macroeconomic conditions in Indonesia. The equation proposed in this study is:
$D_{t}=+A_{1} D_{t-1}+A_{2} P_{t-1}+A_{3} U_{U_{t-1}}+A_{4} U_{L N N_{t-1}}+A_{5} I N F_{t-1}+A_{6} E_{\text {EXCHANGE }}$ ${ }_{1}+A_{7} M M D_{+}$

Vector Error Correction Model (VECM) analysis is a model used when the cointegration test results show the results that the error variables in the equation cointegrate. According to (Widarjono, 2013) VECM analysis serves to show the effect of each variable on other variables on past values and explain the shortterm behavior of the long-term behavior of the research variables. VECM estimation in this study uses Eviews 10 software, for each variable, namely: budget deficit, state revenue, domestic debt, foreign debt, inflation, exchange rates and world crude oil prices. Furthermore, in the implementation of the VECM analysis, it will use the results of the unit root test with break points in analyzing fiscal sustainability, and long-term estimates, Impulse Responses Function (IRF) and Forecast Error Decomposition Variance (FEDV).

\section{Result and Discussion}

In using the VECM model, the data must be stationary as indicated by a mean value and constant variance. The null hypothesis in the Augmented Dickey Fuller (ADF) test and the Philips Perron (PP) test will be rejected when the probability value is smaller than the critical value at the five percent level and the null hypothesis will be accepted when the probability value is greater than 0.05 .

Table 2. ADF Test Results and PP Test

\begin{tabular}{|c|c|c|c|c|c|c|c|c|}
\hline \multirow{3}{*}{ Variebel } & \multicolumn{2}{|c|}{ ADF Test } & \multicolumn{2}{|c|}{ PP Test } & \multicolumn{2}{|c|}{ ADF Test } & \multicolumn{2}{|c|}{ PP Test } \\
\hline & \multicolumn{4}{|c|}{ Level of Level } & \multicolumn{4}{|c|}{ First Difference } \\
\hline & T-stat & Prob & T-stat & Prob & T-stat & Prob & T-stat & Prob \\
\hline DA & -1.275 & 0.634 & -7.567 & $0.000^{*}$ & -8.898 & $0.000^{*}$ & -30.532 & $0.000 *$ \\
\hline PN & -2.167 & 0.220 & -3.341 & $0.017^{* *}$ & -4.857 & $0.000 *$ & -27.651 & $0.000 *$ \\
\hline UDN & -0.946 & 0.766 & -0.971 & 0.758 & -7.807 & $0.000 *$ & -7.876 & $0.000 *$ \\
\hline ULN & 2.0735 & 0.999 & 2.0735 & 0.999 & -6.458 & $0.000^{*}$ & -64318 & $0.000 *$ \\
\hline INF & -6.929 & $0.000^{*}$ & -6.932 & $0.000 *$ & -8.168 & $0.000 *$ & -37.307 & $0.000 *$ \\
\hline $\begin{array}{c}\text { Exchange } \\
\text { Rate }\end{array}$ & -0.016 & 0.953 & -0.296 & 0.919 & -6392 & $0.000^{*}$ & -5.796 & $0.000 *$ \\
\hline MMD & -2.913 & $0.050^{* *}$ & -2.637 & 0.091 & -5.787 & $0.000 *$ & -5.991 & $0.000 *$ \\
\hline
\end{tabular}


Information

* Significant $1 \%$

** Significant $5 \%$

*** Significant $10 \%$

Source: data processed (2020)

Based on the test results in table 2 it can be seen that at the level of the level only variable budget deficit, state revenue, and stationary inflation at the level of $5 \%$, while other variables and overall stationary at the first difference level. From these results, it is necessary to test Johansen Cointegration Test to see the cointegration of variables in research in the long run.

Table 3. Johansen Cointegration Test Results

\begin{tabular}{cccccc}
\hline $\begin{array}{c}\text { Hypothesized } \\
\text { No. of CE(s) }\end{array}$ & :igenvalue & \multicolumn{2}{c}{ Trace } & \multicolumn{2}{c}{ Max-Eigen } \\
\cline { 3 - 6 } & & Stat & :ritical Value (5\%) & Stat & $\begin{array}{c}\text { :ritical Value } \\
\text { (5\%) }\end{array}$ \\
\hline None & 0.74417 & 89.215 & 125.6154 & 79.070 & 46.2314 \\
At most 1 & 0.44411 & 10.145 & 95.7536 & & \\
At most 2 & 0.43598 & 76.088 & 69.8188 & & \\
\hline
\end{tabular}

Source: data processed (2020)

The cointegration test results in table 3 show that all variables in the study are cointegrated in the long run. This is evidenced through the Trace Statistics and Max Eigen Statistics values which are higher than the critical value at the $5 \%$ level. The next step needed is determining the optimum lag. The optimum lag is needed to find out how much lag is used in the VECM testing phase. Table 4 displays the optimum lag test results as follows:

Table 4. Results of Determination of Optimum Lag

\begin{tabular}{cccc}
\hline Lag & AIC & SC & HQ \\
\hline $\mathbf{0}$ & -1.773953 & -1.518474 & -1.675157 \\
$\mathbf{1}$ & -9.833981 & $-7.790151^{*}$ & $-9.043616^{*}$ \\
\hline
\end{tabular}

רdicates lag order selected by the criterion

C: Akaike information criterion

z: Schwarz information criterion

Q: Hannan-Quin information criterion

Source: data processed (2020)

Based on the results of determining the optimum lag, it is known that the optimum lag used in this VECM test is 1 which is based on the Akaike Information Criterion (AIC), Schwarz Information Criterion (SC) and Hannan-Quin Information Criterion (HQ) criteria. VECM estimation with optimum lag 1 in the long run shows the relationship between the budget deficit and the independent variables. The estimation results show that the state revenue, domestic debt, foreign debt, and exchange rates have a significant effect, while inflation and world crude oil prices have no significant effect on long-term.

\section{Long-term VECM Estimation}

$$
\begin{aligned}
& D A_{t-1}=-10.808-0.849 P N_{t-1}+2.397 U D N_{t-1}-1.879 U L N_{t-1}-0.150 I N F_{t-1}+1.726 \text { Kurs }_{t-1} \\
&- 0.174 M M D_{t-1}
\end{aligned}
$$

In the long run, it shows that when state revenues increase in the previous period, it can reduce the budget deficit similar thing happens when the government takes foreign debt to increase the rate of economic growth this will reduce the amount of the government budget deficit. However, the domestic 
debt which has increased drastically since 2007 could be at risk of increasing the budget deficit as well as the condition of an increased nominal exchange rate (depreciated rupiah) will burden the government in paying off debt and interest in the form of foreign exchange.
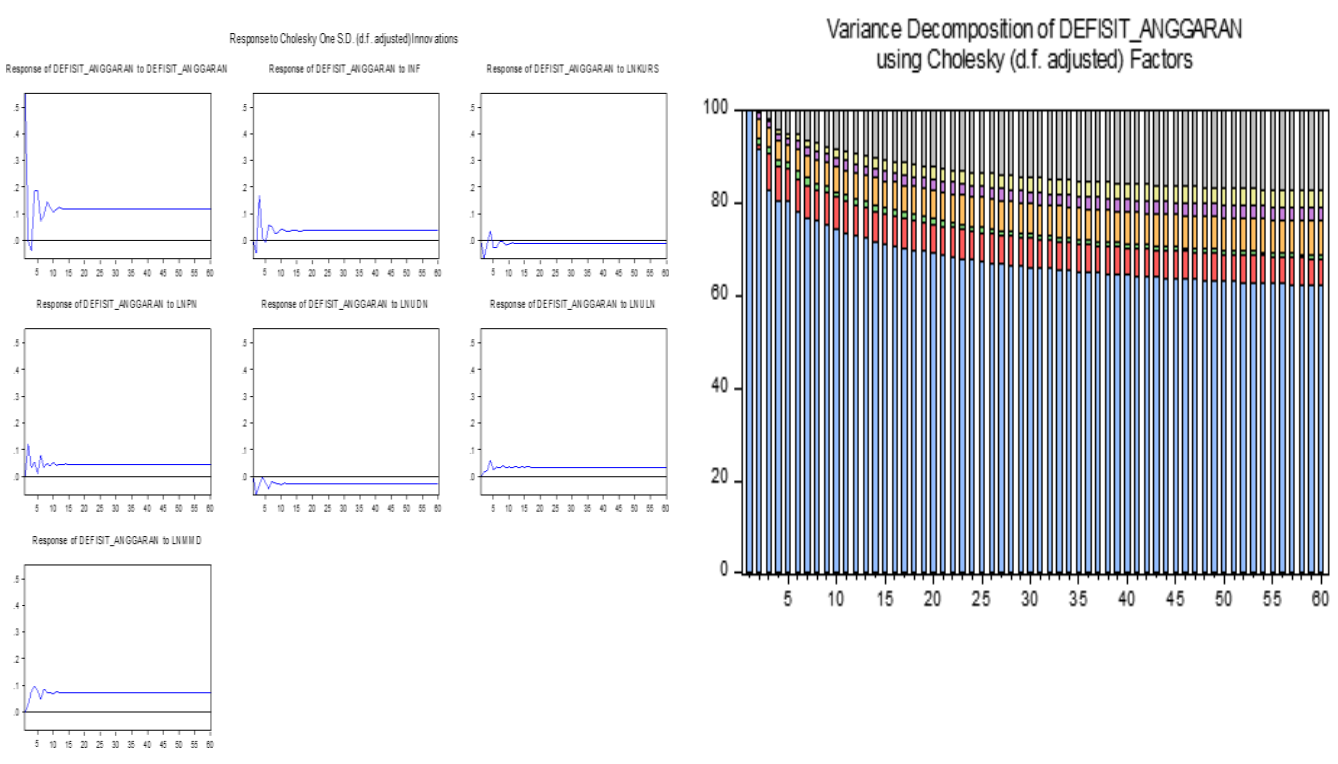

Figure 1. Impulse Response Funcion and Variance Decomposition Test Results Source: data processed (2020)

Impulse Response Function Test (IRF) serves to present information on how long the influence of a shock of a variable in the future if there is interference with other variables and provides information about which variable has the biggest response when a shock occurs. The line on the vertical wave indicates the standard deviation value used to measure how much response a variable will give when a shock occurs on another variable, while the horizontal axis informs the future period of the response given to the shock. Based on Figure 1 above, the budget deficit gives a positive response when there is a shock to the variable state revenue, foreign debt, inflation and world crude oil prices, while when there is a shock to the variable domestic debt and the exchange rate this is in a negative response to the budget deficit. Looking at the magnitude of the contribution caused by each variable to the budget deficit based on the results of the VD test shows that the largest successive contribution to the budget deficit variable is world crude oil prices, state revenue, inflation, foreign debt, domestic debt and the exchange rate.

Based on the estimation of the Schwarz Criterion Test with break points, the following results are obtained

Table 5. Results of the Schwarz Criterion Test with Break Test

\begin{tabular}{cccc}
\hline Variabel & \multicolumn{3}{c}{ Schwarz Criterion Test } \\
\cline { 2 - 4 } & T-Statistik & Prob & Break Date \\
\hline Government Budget & -10.60746 & $<0.01^{*}$ & 2009: Q4 \\
Deficit & & & \\
Government Revenue & -11.49331 & $<0.01^{*}$ & $2004: \mathrm{Q} 4$ \\
Domestic Debt & -4.464342 & 0.1436 & $2010: \mathrm{Q} 3$ \\
Foreign debt & -3.993209 & 0.3757 & $2005: \mathrm{Q} 4$ \\
Inflation & -11.13840 & $<0.01^{*}$ & $2005: \mathrm{Q} 4$ \\
Exchange rate & -3.817595 & 0.4894 & $2013: \mathrm{Q} 2$ \\
World Crude Oil Prices & -5.659277 & $<0.01^{*}$ & $2014: \mathrm{Q} 3$
\end{tabular}




\section{Critical Value Test}

$\begin{array}{cc}1 \% & -5.347598 \\ 5 \% & -4.859812 \\ 10 \% & -4.607324\end{array}$

Source: data processed (2020)

From the results of the analysis above shows a break occurred in a certain period resulting from the economic crisis and other economic problems both at home and abroad that can impact on economic conditions in Indonesia. During the observation period it can be said that fiscal conditions in Indonesia are sustainable if the break in 2004QI, 2005QIV and 2009QIV are considered. Economic conditions at the time of the break occurred in 2004QI allegedly due to the impact of the Fed's decision to increase interest rates from $1.25 \%$ in 2004 and increased to reach $5.25 \%$ in 2006 (Bank Indonesia, 2013). The second condition in the 2005QIV break occurred due to an increase in world crude oil prices which reached 15 dollars / barrel so that the government reduced the amount of fuel subsidies, this resulted in increased fuel prices and this coincided with the Islamic holiday so that the inflation in 2005 reached $17.89 \%$.

The third condition during the break in 2009QIV was the impact of the subprime mortage crisis. The impact of the global financial crisis on the Indonesian economy began to have an impact in the fourth quarter of 2008 where economic growth fell by $3.6 \%$ compared to the third quarter of 2008 (q-toq). In addition, there was also a decline in exports and a significant slowdown in investment growth until the end of 2009 (Ministry of Industry, 2011). Taking into account the economic conditions that occur that the fiscal conditions in Indonesia are still vulnerable, especially to external shocks that have an impact on domestic economic conditions. This is in accordance with research conducted by Dewi (2017)which says that the condition of fiscal sustainability in Indonesia can be met if the break in 1977 is considered.

The government has a large role in maintaining the condition of fiscal sustainability in the period 2004-2018 in the form of policies or laws related to state finance and debt management. Today, the government is trying to increase state revenue by implementing a tax revenue reform mechanism that is carried out by integrating tax data and information, raising awareness of taxpayers (sustainable compliance), improving services, increasing the tax base and preventing the practice of tax avoidance and the imposition of tax incentives. In addition, the government is also trying to control the debt burden, one of which is by shifting foreign debt into domestic debt, bearing in mind that Indonesia has a risk of exchange rate fluctuations (Marisa, 2015).

Macroeconomic variables have a large impact on the condition of fiscal sustainability as proxied by a budget deficit. Based on the results of the VECM estimate that the government's decision to say that the deficit must be financed by domestic financial sources, where the Consultative Group on Indonesia (CGI), which functions as a permanent container for Indonesian donors, where the CGI annually provides funds sourced from IMF, UNDP, World Banks and developed countries were dissolved in 2007 . Financing of the deficit financed by domestic finance has resulted in Indonesia's domestic debt stock surging when compared to foreign debt, so this has also resulted in an increase in public debt interest whose value far exceeds the interest on foreign debt which which this raises the risk of increasing budget deficits. This finding is in line with Haerani (2012)who concluded that domestic debt has a significant positive effect on the state budget deficit.

In contrast to foreign debt, based on the estimation results, it shows a negative relationship to the budget deficit even though foreign debt carries a risk to the exchange rate. This is because in the theory of the three gap model proposed by Chenery \& Bruno(1962) states that foreign debt can be allocated to fill the gap that occurs. The gap / gap referred to is 
the current transaction gap (current account gap), the budget gap (budget gap) and the investment-saving gap (investment-saving gap).

Considering that Indonesia experiences a savings investment gap that always shows a negative value or nett borrowing with a value of -211.67 trillion in 2013 and increased dramatically to -340.98 trillion in 2017 (Indonesia's Funds Flow Balance, 2018). So debt is needed to fill the gap that occurs to function as a provider of capital needs for government and private investment. This shows that the increase in foreign debt is able to reduce the government budget deficit which this statement is in accordance with Kusumo (2008)which says that the cumulative reduction in the amount of foreign government debt will cause the sectoral growth indicator numbers to decrease and reduce the macro economy so that it results in the increasing budget deficit figure .

Inflation risk also affects the increase in government burden, where the estimation results show inflation has a positive effect on the budget deficit. This risk will result in prices that will increase resulting in decreased purchasing power and public consumption as well as sluggish production, which in turn will cause a country's real GDP to fall due to the resulting low real output. This has consequences for widening government budget deficits and disrupting fiscal sustainability because with low income the government must continue to meet the needs of its people. Risk is in line with the results of research conducted by Harahap(2016) that in the initial to the third period the budget deficit response to the shock of negative inflation, then in the fourth period to the end of the observation period showed a positive response to the shock of rising and falling inflation.

\section{Conclusion and Recommendation}

This study aims to analyze the condition of fiscal sustainability in Indonesia and the effect of macroeconomic variables on fiscal sustainability by using a proxy for budget deficits. By using time series data and the Schwarz Criterion Test with break point analysis tool to analyze fiscal sustainability and the Vector Error Correction Model (VECM) analysis to determine the impact of macroeconomic variables on fiscal sustainability in Indonesia. Based on research results it is known that fiscal conditions in Indonesia are sustainable with Considering the break in 2004QI, 2005QIV and 2009QIV, these conditions will be vulnerable to shocks from instability in the global economy.

In addition, this study also found that state revenue and foreign debt had a significant negative impact on the budget deficit in the long run, indicating that when state revenue and foreign debt increase, this would reduce the budget deficit. Whereas domestic debt and inflation variables have a significant positive effect on the budget deficit. This condition shows that the increase in domestic debt and rising inflation will be followed by worsening budget deficit conditions.

\section{References}

[1] Adams, C., Ferrarini, B., \& Park, D. 2010. "Fiscal sustainability in developing Asia". Asian Development Bank Economics Working Paper Series, 205.

[2] Bank Indonesia. 2013. "Seri Kebijakan Moneter."Gerai Info Bank Indonesia, Issue 40 Year 4, page 7.

[3] Burnside, C., \& Dollar, D. 2000. "Aid, policies, and growth". American economic review, 90(4), 847-868.

[4] Chenery, H. B., \& Bruno, M. 1962. "Development alternatives in an open economy: The case of Israel". The Economic Journal, 72 (285), 79-103.

[5] Cuddington, J. T. 1999. "Analyzing the sustainability of fiscal deficits in developing countries". The World Bank.

[6] Dewi, Ratna E.,\& Artidiatun A. 2017. "Keberlanjutan Fiskal dan Fungsi Reaksi Fiskal di Indonesia, 1980-2015."Thesis. Yogyakarta: Economic Science, Gadjah Mada University. 
[7] Haerani, Wiwin. 2012. "Analisis Faktor-Faktor yang Mempengaruhi Defisit APBN di Indonesia Periode Tahun 2001-2010."Thesis. Makasar: Faculty of Economics and Business, Hasanuddin University.

[8] Harahap, I. 2016. "Analisis kausalitas variabel makro ekonomi terhadap Anggaran dan Pendapatan dan Belanja Negara di Indonesia periode 19902015". FEBI UINSU Press.

[9] Hidayah, M. 2012. "Analisis Keberlanjutan Fiskal dan Utang Pemerintah Terhadap Keseimbangan Primer di Indonesia, 2000.1-2014.4: Pendekatan Error Correction Model (ECM)."Jogjakarta: Gadjah Mada University.

[10] Indonesia Funds Flow Balance 2018.

[11] Kuncoro, H. 2011. "Ketangguhan APBN dalam pembayaran utang". Buletin Ekonomi Moneter dan Perbankan, 13(4), 433-454.

[12] Kusumo, B. S. 2008. "Dampak Utang Luar Negeri Pemerintah Terhadap Kinerja Perekonomian Indonesia."Dissertation. Bogor: Bogor Agricultural Institute Graduate School.

[13] Manurung, Mandala. 2009. "Analisis Keberadaan Utang Indonesia dan Dampak Defisit Anggaran terhadap Keberlanjutan Fiskal". Journal of Economic Policy. Vol 2 No. 1. Pages 25-58.

[14] Marisa, R. 2015. "Analisis keberlanjutan fiskal Indonesia tahun 2000-2012". Bina Ekonomi, 19(1), 1-14.

[15] Raymundo, R. B. 2016. "Fiscal Sustainability and Sovereignty Issues under an Asean Economic Union". DSLU Research Congress, De La Salle University, Manila, Philippines, March, 7-9.

[16] Stoian, A., \& Campeanu, E. 2010. "Fiscal Policy Reaction in the Short Term for Assessing Fiscal Sustainability in the Long Run in Central and Eastern European Countries". Finance a Uver: Czech Journal of Economics \& Finance, 60(6).

[17] The Ministry of Industry of the Republic of Indonesia. 2011. "Laporan Evaluasi Kinerja Ekonomi Tahun 2010."

[18] Wardhono, A., Qori'ah, C. G., \& Wulandari, C. D. A. 2015. "Studi kesinambungan fiskal pada variabel makro ekonomi Indonesia: Analisis VAR". Jurnal Ekonomi Kuantitatif Terapan, 8(2), 113-121.

[19] Widarjono, A. 2013. "Ekonometrika". UPP STIM YKPN. Yogyakarta. 